\title{
Diffuse Endocrine System, Neuroendocrine Tumors and Immunity: What's New?
}

\author{
Pietro Ameri Diego Ferone \\ Department of Internal Medicine and Center of Excellence for Biomedical Research, University of Genoa, Genoa, Italy
}

\section{Key Words}

Neuroendocrine tumors $\cdot$ Immunity $\cdot$ Neuropeptides .

Somatostatin $\cdot$ Cortistatin

\begin{abstract}
During the last two decades, research into the modulation of immunity by the neuroendocrine system has flourished, unravelling significant effects of several neuropeptides, including somatostatin (SRIH), and especially cortistatin (CST), on immune cells. Scientists have learnt that the diffuse neuroendocrine system can regulate the immune system at all its levels: innate immunity, adaptive immunity, and maintenance of immune tolerance. Compelling studies with animal models have demonstrated that some neuropeptides may be effective in treating inflammatory disorders, such as sepsis, and T helper 1-driven autoimmune diseases, like Crohn's disease and rheumatoid arthritis. Here, the latest findings concerning the neuroendocrine control of the immune system are discussed, with emphasis on SRIH and CST. The second part of the review deals with the immune response to neuroendocrine tumors (NETs). The anti-NET immune response has been described in the last years and it is still being characterized, similarly to what is happening for several other types of cancer. In parallel with investigations address-
\end{abstract}

ing the mechanisms by which the immune system contrasts NET growth and spreading, ground-breaking clinical trials of dendritic cell vaccination as immunotherapy for metastatic NETs have shown in principle that the immune reaction to NETs can be exploited for treatment.

Copyright $\odot 2012$ S. Karger AG, Basel

\section{Introduction}

The anatomical organization and the functions of the diffuse (neuro)endocrine and immune systems are exceedingly complicated, and the more we discover the more new questions arise. The diffuse endocrine system (DES) is composed of neuroendocrine cells scattered throughout the entire body, either isolated or grouped to form discrete aggregates, such as the neuroepithelial bodies in the bronchopulmonary tract or the islets of Langerhans in the pancreas [1]. While at least some of the DES cells in the gut are known to regulate secretion, absorption, motility, and mucosal proliferation [2], the physiological role of the neuroendocrine cells in most other organs remains elusive.

The immune system includes two branches, i.e. innate immunity, which is evolutionarily older, and adaptive

\section{KARGER \\ Fax +4161306 1234 \\ E-Mail karger@karger.ch}

www.karger.com
(C) 2012 S. Karger AG, Basel

$0028-3835 / 12 / 0954-0267 \$ 38.00 / 0$

Accessible online at:

www.karger.com/nen
Diego Ferone

Department of Internal Medicine and Center of Excellence for Biomedical Research University of Genoa, Viale Benedetto XV, 6 IT-16132 Genoa (Italy)

Tel. +39010 353 7946, E-Mail ferone@ unige.it 


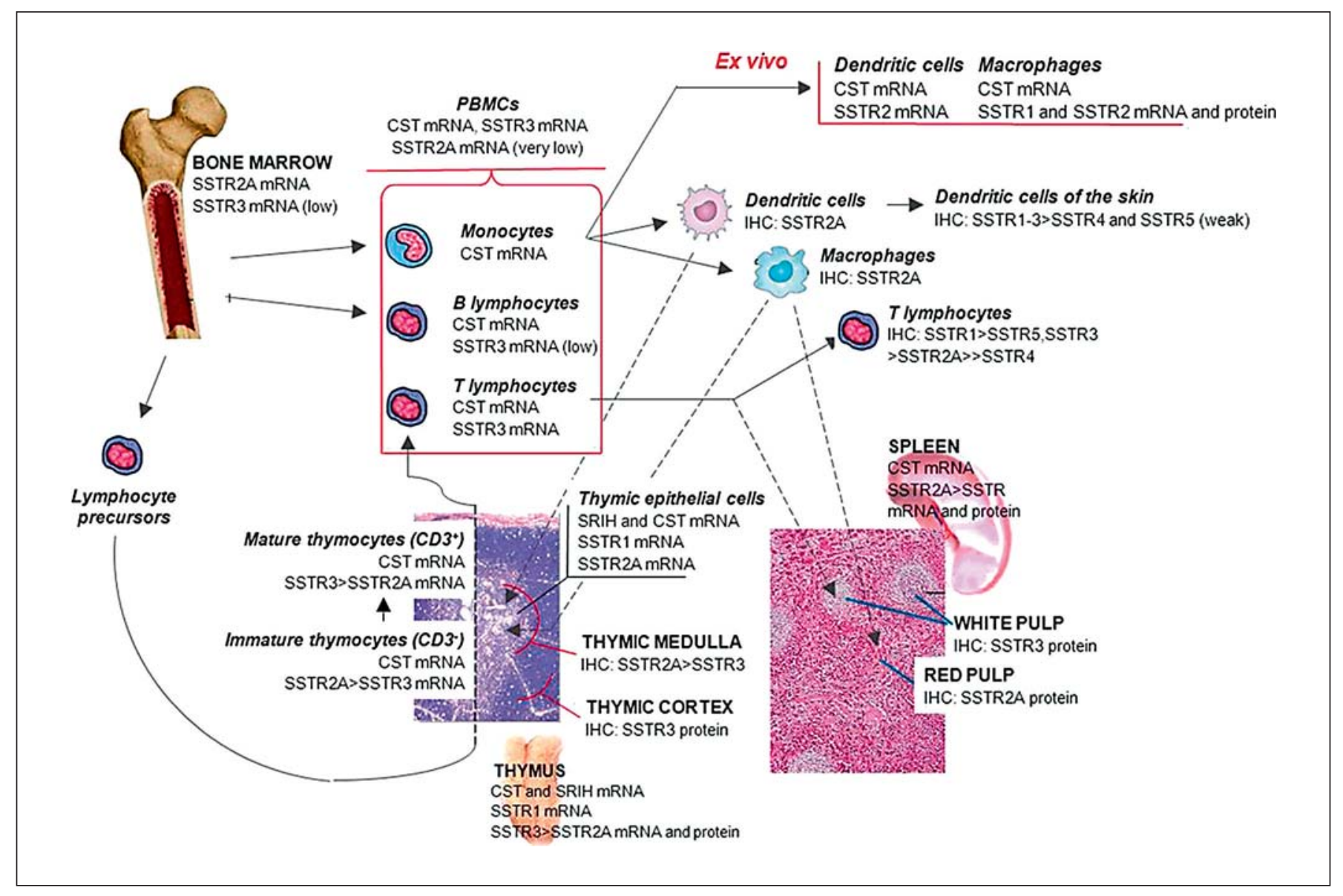

Fig. 1. Expression of somatostatin (SRIH), cortistatin (CST), and somatostatin receptors (SSTR) 1-5 in the immune system. As shown by Lichtenauer-Kaligis et al. [8], already a minimal activation of monocytes isolated from peripheral blood mononuclear cells (PBMCs) induces the expression of the SSTR2A mRNA. IHC = Immunohistochemistry.

immunity [3]. The complement, neutrophils, mast cells, eosinophils, and basophils are central to the first, lymphocytes are the cornerstone of the second, and phagocytic cells (monocyte/macrophages and dendritic cells, DCs) are at the interface between the two. Innate immunity provides generic, non-pathogen-specific, and - most notably - short-term protection. In contrast, the adaptive immunity's defense is specific and lasts much longer (see also the relevant paragraph).

Historically, studies on the interactions between the DES and the immune system have been addressed to establish whether and how the first influences the latter. This research direction was taken as early as the DES began to be characterized, when neuroendocrine cells were found in lymphoid organs and neuroendocrine mediators (biogenic amines, neuropeptides) and their receptors in immune cells, suggesting the existence of a neuroendocrine modulation of immune functions, based on a biochemical language of autocrine, paracrine, and endocrine signals [4]. As exemplified by somatostatin receptors (SSTR) 1-5 (fig. 1) [5-12], the expression profile of many neuropeptide receptors varies across different types of immune cells, and changes upon their differentiation or activation status, further pointing to a fine regulation of immunity by neuropeptides [13]. For instance, human monocytes do not transcribe any SSTR gene in resting conditions, but express SSTR2A when activated with lipopolysaccharide, and both SSTR1 and SSTR2A when induced to differentiate into macrophages or DCs [7-9]. In vivo, SSTR2A is present on the membrane of macrophages and DCs $[5,11,12]$, making tissues physiologically or pathologically rich of SSTR2A detectable 
Fig. 2. The somatostatinergic anti-inflammatory loop. Noxious stimuli cause sensory nerve fibers to release pro-inflammatory neuropeptides, such as substance $\mathrm{P}$ (SP) or calcitonin gene-related peptide (CGRP), which then drive local neurogenic inflammation. However, the same peptidergic nerve endings release also somatostatin (SRIH), which stops its own, SP, and CGRP exocytosis, and inhibits inflammation both locally and far from the site of release.

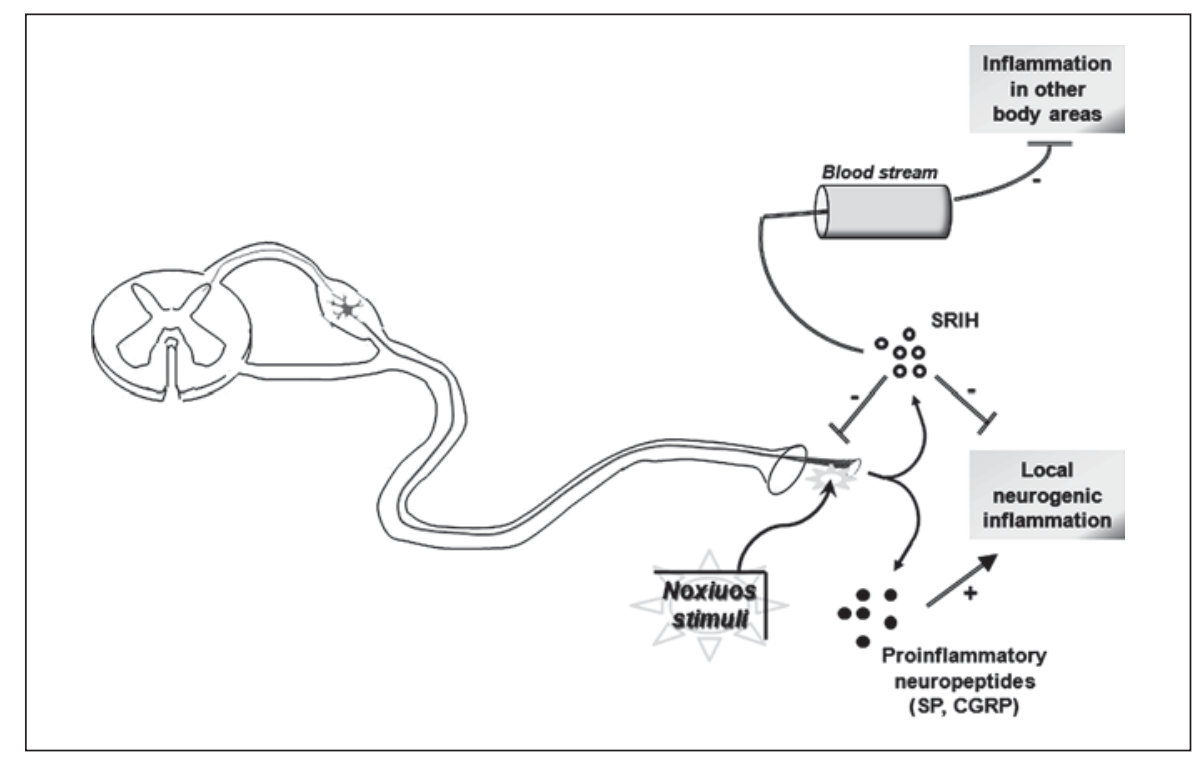

by SSTR scintigraphy with radiolabelled somatostatin (SRIH) analogs having high affinity for SSTR2A, such as the routinely used ${ }^{111}$ In-pentetreotide $\left(\right.$ Octreoscan $\left.^{\circledR}\right)$ $[12,13]$.

The analysis of the expression profile of neuropeptides and their cognate receptors in immune cells has been paralleled by the study of animal models and, to a far lesser extent, human diseases. As a result, we have been able to partially understand the meaning of the biochemical language connecting the endocrine and immune systems.

\section{Regulation of Immunity by the DES}

\section{Innate Immunity}

Inflammation is a stereotyped, but essential, innate immunity response. Completing a previous, detailed research work on neuropeptide-induced inflammation [14], a SRIH-mediated anti-inflammatory loop has been fully characterized in rodents in recent times (fig. 2).

Trigeminal and dorsal root ganglia contain the cell bodies of capsaicin-sensitive sensory neurons, whose unmyelinated or thinly myelinated fibers transmit electrical impulses coding for pain to the central nervous system (CNS) [14]. The nociceptive nerve terminals express the transient receptor potential vanilloid 1 (TRPV1) protein, a cation channel which binds several ligands, including capsaicin. TRPV1-dependent and -independent stimulation of capsaicin-sensitive nerve endings triggers the re- lease of substance $\mathrm{P}(\mathrm{SP})$ and calcitonin gene-related peptide (CGRP), that initiate inflammation: in this way, nociception is immediately coupled to a neurogenic inflammatory response against noxious, potentially tissue-damaging stimuli $[14,15]$. In extreme cases, irritation of a deep organ, such as the colon, may lead to 'crosssensitization' and neurogenic inflammation of another otherwise healthy organ, e.g. the bladder, via reflexes through axon collaterals in the spinal cord and/or in the brain [16]. Besides SP and CGRP, other neuropeptides can mediate neurogenic inflammation, such as neurokinin A [17]. Noteworthy, the same neuropeptides that drive neurogenic inflammation may be protective of tissue homeostasis in other contexts. For instance, in type 1 diabetes mellitus-prone NOD mice, a hypofunctional mutant TRPV1 receptor leads to depressed neurogenic inflammation, but also to $\beta$-cell stress and autoimmune insulitis, secondary to deficient release of SP into the pancreatic islets of Langerhans by TRPV1-expressing sensory neurons [18].

Capsaicin-sensitive, TRPV1-positive fibers contain also SRIH and release it upon TRPV1 receptor activation [19]. Neuronally-derived SRIH acts in a paracrine/autocrine fashion, but also enters the circulation. In the same body area where it has been released, SRIH binds to presynaptic SSTRs and stops its own, SP, and CGRP exocytosis with negative feedback $[14,20]$. Moreover, SRIH from peptidergic nerve endings can inhibit the pro-inflammatory responses of neutrophils, macrophages, lymphocytes [21], as well as of non-immune cells like vascu- 
lar endothelial cells, smooth muscle cells [21], and intestinal epithelial cells [22]. This inhibitory activity of SRIH on the effectors of inflammation is both local and systemic, via the bloodstream; in the latter case, SRIH can operate as an anti-inflammatory hormone (fig. 2). SRIH might also contribute to the anti-inflammatory action of glucocorticoids, which have been reported to stimulate SRIH expression at the inflammatory site in rats [23]. Analgesia is another effect of SRIH, obtained by inhibiting peripheral nerve firing and acting within the CNS [14]. Clinically, SRIH analog-induced analgesia is effective in controlling headache in patients with acromegaly, and partly also cancer pain in advanced neuroendocrine tumors (NETs).

A significant anti-inflammatory effect of SRIH has been demonstrated in different animal models in which the experimental induction of inflammation is associated with capsaicin-sensitive nerve terminal stimulation, such as arthritis, subacute pneumonia, and contact dermatitis $[19,24]$. Recently, elegant studies with SSTR4 ${ }^{-/}$ animals have revealed that this SSTR subtype is crucial for SRIH anti-inflammatory effects in mice [24, 25].

Cortistatin (CST) is a neuropeptide with strong homology to SRIH, which can bind to SSTRs with the same high affinity as SRIH, and with lower affinity to type la growth hormone secretagogue receptor (GHS-Rla) and Mas-related gene (Mrg) X2 receptor [26], the latter being interestingly highly expressed in dorsal root ganglia [27]. CST has been shown to inhibit the production of proinflammatory cytokines and nitric oxide by activated macrophages, and stimulate the secretion of the anti-inflammatory cytokine interleukin (IL)-10, up to affecting circulating levels of these molecules and strikingly improve survival and clinical outcomes in mouse models of sepsis, Crohn's disease, and rheumatoid arthritis [28-30]. Therefore, two different ligands can activate SSTRs to dampen inflammation. However, CST anti-inflammatory action appears to be stronger than that of SRIH, possibly because of CST binding to GHS-R1a (and hypothetically also to MrgX2). In animals, cyclosomatostatin, a SSTR-antagonist, fully blocked the anti-inflammatory effect of SRIH, but not of CST, while a GHS-R antagonist partially antagonized CST activity [28-30]. In addition, only CST inhibited basal and IL-1 $\beta$-stimulated release of prostaglandin $\mathrm{E}_{2}$ by primary rat microglia, a population of CNS-resident macrophage-like cells [31]: thus, CST action on innate immunity cells might also be broader than that of SRIH. Noteworthy, CST, but not SRIH, mRNA can be detected in human monocyte-macrophages, and is upregulated upon activation in parallel with SSTR2 mRNA, suggesting the existence of an autocrine CST-SSTR2 loop (fig. 1) $[7,8]$.

In protecting mice exposed to lipopolysaccharide from endotoxemia, CST was synergic with vasoactive intestinal polypeptide (VIP) [28], which has also been shown to inhibit macrophage and microglia release of pro-inflammatory cytokines, chemokines, free radicals, nitric oxide, and prostaglandin $\mathrm{E}_{2}$, and to stimulate the secretion of IL-10 $[32,33]$. Both VIP and ghrelin also blocked lipopolysaccharide-activated macrophages from secreting high mobility group box 1 (HMBG1), a DNAbinding protein considered a necessary and sufficient late mediator of multiple organ failure in advanced sepsis [34].

Sepsis is probably the best scenario to pinpoint the strength of the anti-inflammatory activity of neuroendocrine mediators, since it results merely from an excessive systemic inflammatory response to infectious agents. Those neuropeptides which also have antimicrobial activities, such as ghrelin [35], are expected to be the most protective in sepsis, because of their capability of inhibiting not only inflammation, but also the replication of the microorganisms against which inflammation is mounted. Eventually, this category of neuropeptides, or even better their analogs, might be designed for therapy [36].

Despite the abundance of experimental data, and the report of increased SRIH-like immunoreactivity in the blood of patients with sepsis or undergoing surgery [37], there is yet no direct evidence that SRIH from capsaicinsensitive nerves or CST from other sources inhibit inflammation also in humans, and that lack of SRIH and/ or CST feedback may lead to increased susceptibility to developing more severe inflammatory reactions.

More in general, it has been hypothesized that in humans inflammation activates the DES, because increased serum values of chromogranin $\mathrm{A}(\mathrm{CgA})$ are found in patients with chronic inflammatory disorders, such as inflammatory bowel diseases [38], rheumatoid arthritis [39], systemic lupus erythematosus [39], and bronchitis [40]. Tumor necrosis factor- $\alpha$ (TNF- $\alpha$ ) might be the main stimulus for neuroendocrine cell activation, since concentrations of $\mathrm{CgA}$, TNF- $\alpha$, and its soluble receptors are positively correlated $[38,41]$. Interestingly, $\mathrm{CgA}$ and its breakdown products have been shown to protect the endothelium from TNF- $\alpha$-induced inflammatory changes [42]. However, the increase in $\mathrm{CgA}$ in human inflammatory diseases may reflect reactive hyperplasia of the DES or hyperactivity of the adrenal medulla, rather than a finalized feedback neuroendocrine response to inflammation $[38,39]$. Neither implies the raise of $\mathrm{CgA}$ 
levels that other neuropeptides and/or amines are secreted and somehow involved in tuning the ongoing inflammation.

\section{Adaptive Immunity}

In superior species, the immune system is able to expand different subsets of T cells for every pathogen, which will then be attacked in a specific manner. Antigen-specific clones of $\mathrm{T}$ lymphocytes undergo activation and expansion when they recognize peptides derived from a pathogen, properly presented with major histocompatibility complex (also known as human leukocyte antigen, HLA) molecules by antigen-presenting cells, especially DCs. This capability of adaptation, referred to as adaptive immunity, ensures a much higher level of protection than first-line innate immunity [3]. CD4+ T helper (Th) lymphocytes orchestrate the adaptive immune response, by secreting different cytokine patterns according to the stimuli received during their activation, including those brought on by neuropeptides [43]. For instance, it has been demonstrated in mice that SRIH and VIP favor the development and maintenance of a Th2 response, typically involved in helminthic infections and allergy, over a Th1 one, which instead occurs in the presence of intracellular pathogens $[32,44]$. This modulation seems to be relevant in humans too, since in more than 300 children serum levels of SRIH and VIP have been associated with circulating Th2 cytokines, expression of Th2 transcription factors in T cells, and allergic sensitization [45]. Exploiting the potential of some neuropeptides of determining a Th2 bias might be of value to treat Th1-driven autoimmune processes, such as sarcoidosis [13], multiple sclerosis [46], Crohn's disease, and rheumatoid arthritis [32]. In animal models of the latter two, CST selectively inhibited the release of Th1 cytokines by CD4+ lymphocytes infiltrating the colon or joints, respectively, and the draining lymph nodes, without affecting the levels of the Th2 signature cytokine IL-4 $[29,30]$.

Adaptive immunity is achieved through the activity of $\mathrm{T}$ cells against foreign or abnormal (non-self) cells which are to be destroyed. When lymphocytes reactive against self-tissues, which are to be 'tolerated' and preserved, are generated and/or not suppressed, the system becomes potentially harmful to the host itself [32, 47]. In general, autoimmunity is underlain by ineffective control of autoreactive $\mathrm{T}$ cells, a function for which regulatory $\mathrm{T}$ cells (Treg) play a primary role. Treg are lymphocytes shown to be crucial in sustaining self-tolerance and preventing the development of autoimmune processes by inhibiting autoreactive effector cells [47]. The most extensively char- acterized Treg population expresses the surface marker CD25 (in addition to CD4) and the transcription factor FoxP3 [48].

Naïve T cells in the periphery can be converted into Treg upon particular conditions, such as high concentrations of transforming growth factor (TGF)- $\beta$ [49]. As reviewed by Gonzalez-Rey and colleagues [36], it has been discovered recently that neuropeptides can induce Treg and restore immune tolerance in autoimmune diseases. VIP is the most interesting molecule analyzed so far, because its ability to generate Treg has been proved in primary human T cells [50], and, most notably, in patients affected by sarcoidosis [51]. Although not as thorough as for VIP, evidence has been gained that other neuropeptides, including CST, can expand/generate Treg [29, 30, 32]. Treg induction might be the conceptual basis for preventing the rejection of allogeneic transplants with neuropeptides, through the stimulation of the recipient's immune tolerance to alloantigens (i.e. non-self-antigens of the donor tissue) [52]. In a mouse model of skin transplantation, treatment with CST, but not with the SRIH analog octreotide, almost doubled the survival time of the allograft, and increased CD4+ spleen lymphocytes with a regulatory phenotype [53].

Immune self-tolerance is firstly produced in the thymus, the primary lymphoid organ where bone marrowderived thymocytes maturate to T lymphocytes (fig. 1). In the thymus, autoreactive $\mathrm{T}$ lymphocytes undergo negative selection and elimination [4], and a subset of Treg is generated [47]. Several neuropeptides are present in the thymus, released by sympathetic and parasympathetic nerve fibers, thymic epithelial cells, macrophages, DCs, and lymphocytes themselves $[6,12,54]$. In different animal species and in cell culture systems, some of these neuropeptides, such as SRIH and SP, respectively, have proapoptotic or mitogenic effects on thymocytes $[6,55]$, which makes them potentially involved in causing the survival of self-tolerant and the death of autoreactive T cells.

\section{Immune Response to NETs: The Other Side of the Coin}

Growing attention is being given to the immune response to neoplasms, induced by tumor-associated antigens (TAA), in the light of both a better understanding of tumor biology and technical advances that have made cancer immunotherapy a feasible treatment perspective $[56,57]$. 
Endocrinologists and oncologists have known that immunology may be a key to improve NET management since the introduction of interferon (IFN)- $\alpha$ biotherapy, which directly inhibits NET cell cycle progression and hormone synthesis, reduces neoangiogenesis, and activates immune cells [58]. Other IFN molecules, such as IFN- $\beta$, may have similar or more potent effects than IFN$\alpha[59]$.

Indirect evidence that a functional immune system reacts to growing NETs, and in principle slows down or halts their progression, comes also from the observation that patients affected by X-linked hyperimmunoglobulin $\mathrm{M}$ syndrome (XHIGM), a primary immunodeficiency disorder with defective $\mathrm{B}$ - and T-cell functioning, can develop neuroendocrine carcinoma (NEC) [60]. Erdos and colleagues [60] recently reported a 7-year-old child who died from a poorly-differentiated NEC, retrieved six further published cases of NECs in XHIGM, and found a total of 4 poorly-differentiated NECs in XHIGM out of 6,965 patients registered in the European Society for Immunodeficiencies online database. Although an estimate cannot be equated with reality, an incidence of NECs in XHIGM of 57.4/100,000 can be extrapolated from the ratio $4 / 6,965$, and it might be even higher, since the European database includes other primary immunodeficiencies besides XHIGM.

That an immune response opposes to NETs is also substantiated by the frequent finding of lymphocyte infiltration of NETs, as assessed by immunohistochemistry for CD3 (a general T lymphocyte marker), CD4, and CD8 [61-63]. In the biggest case series analyzed so far, CD3+ T cells were found to infiltrate $68 \%$ of 87 well-differentiated pancreatic NETs. In patients with intermediate-grade tumors who were followed up for more than 5 years, CD3+ $\mathrm{T}$ cell infiltration was a significant univariate predictor of improved recurrence-free survival following surgical resection [63]. CD3+ infiltration was also found in $97 \%$ of 39 resected NET liver metastases, the pancreas being the most common verified primary site [63].

Carcinoid TAA-specific CD8+ T cells have been described in patients with midgut carcinoid tumors $[64,65]$. The highest $\mathrm{CD} 8+\mathrm{T}$ cell recognition was for the TAA $\mathrm{CgA}$, which makes it an attractive target for immunotherapy. Interestingly, IFN- $\gamma$ secretion by CD8+ lymphocytes in response to TAA was significantly higher in patients with a low tumor burden, while those who did not show recognition of any CgA-derived epitope had either very high or low plasma CgA levels. Based on this finding, the authors of the study argue that a minimal tumor bulk is necessary to activate T cells, and there is a thresh- old of NET growth beyond which T cells are anergized or deleted [65].

A subpopulation of DCs with natural killer properties (CD56 positivity, direct cell lysis via tumor necrosis factor-related apoptosis-inducing ligand, activation of $\mathrm{T}$ cells) can be generated in vitro by incubating monocytes with IFN- $\alpha$ [66]. In humans, precursors of these DC subtype might be CD14+/CD56+ monocytes, which are characterized by upregulation of costimulatory molecules chiefly involved in T cell activation, and cytolytic activity toward tumor cells upon stimulation with IFN- $\alpha$ [67]. Significantly more CD14+/CD56+ monocytes have been reported in 4 NEC patients than in healthy control subjects, being $>5 \%$ of all monocytes in 3 cases [67].

As other cancer types, NETs often elude immunosurveillance regardless of the functionality of the immune system: clinicians' experience is that NETs will eventually progress and/or relapse in most immunocompetent patients, if no therapy is given. As illustrated in figure 3, NET cells may escape the immune response in many ways [56].

An altered expression of HLA class I molecules has been demonstrated by immunohistochemistry in 10 out of 11 pancreatic NETs, loss of $\beta 2$-microglobulin being the most frequent alteration [61]. In the absence of HLA class I antigens, TAA-derived peptides cannot be presented to $\mathrm{T}$ cells and the development of a tumor-specific immune response is hindered.

Immune cells can be inhibited by soluble factors secreted by NETs. Generation of DCs from umbilical cord blood precursors was completely abrogated if the latter were incubated with cell-free supernatant from bronchial carcinoid tumor cells, which are therefore likely to produce molecules blocking DC differentiation. Consistently, no CD1a and CD83-positive DCs were found in pulmonary carcinoid tumor samples [68]. Also non-tumor stromal cells may release immune inhibitory factors.

Anti-tumor immune responses can be limited by Treg like any immune response. A heavier tumor infiltration by Treg is associated with weaker anti-tumor immunity and thus worse prognosis [69]. Treg are induced or recruited into the tumor by cytokines and chemokines secreted by cancer cells, tumor-associated macrophages, and DCs, such as TGF- $\beta$ and CCL22, respectively (fig. 3); TAA then drive their expansion [69].

The number of circulating Treg was significantly higher in 68 patients with midgut carcinoid tumors than in 53 healthy blood donors [62]. In a subgroup of 25 patients compared with 18 controls, serum levels of the cytotoxic T lymphocyte-promoting cytokines IL-12p70 and 
Fig. 3. The immune response to neuroendocrine tumors (NETs). The growth of a NET induces a specific, anti-tumor immune response, which is antagonized by several tumor-related factors, as depicted in the lower part of the figure. Tumor-associated antigens (TAA), along with cytokines from NET cells, dendritic cells (DCs), and tumor-associated macrophages, recruit/induce regulatory $\mathrm{T}$ cells (Treg), which inhibit the anti-tumor immune response as well. Whether therapies, including somatostatin analogs (SSA), influence the anti-NET immune response is not known yet. $\mathrm{CT}=$ Chemotherapy; $\mathrm{RT}=$ radiotherapy; $\mathrm{PRRT}=$ peptide receptor $\mathrm{ra}-$ diotherapy.

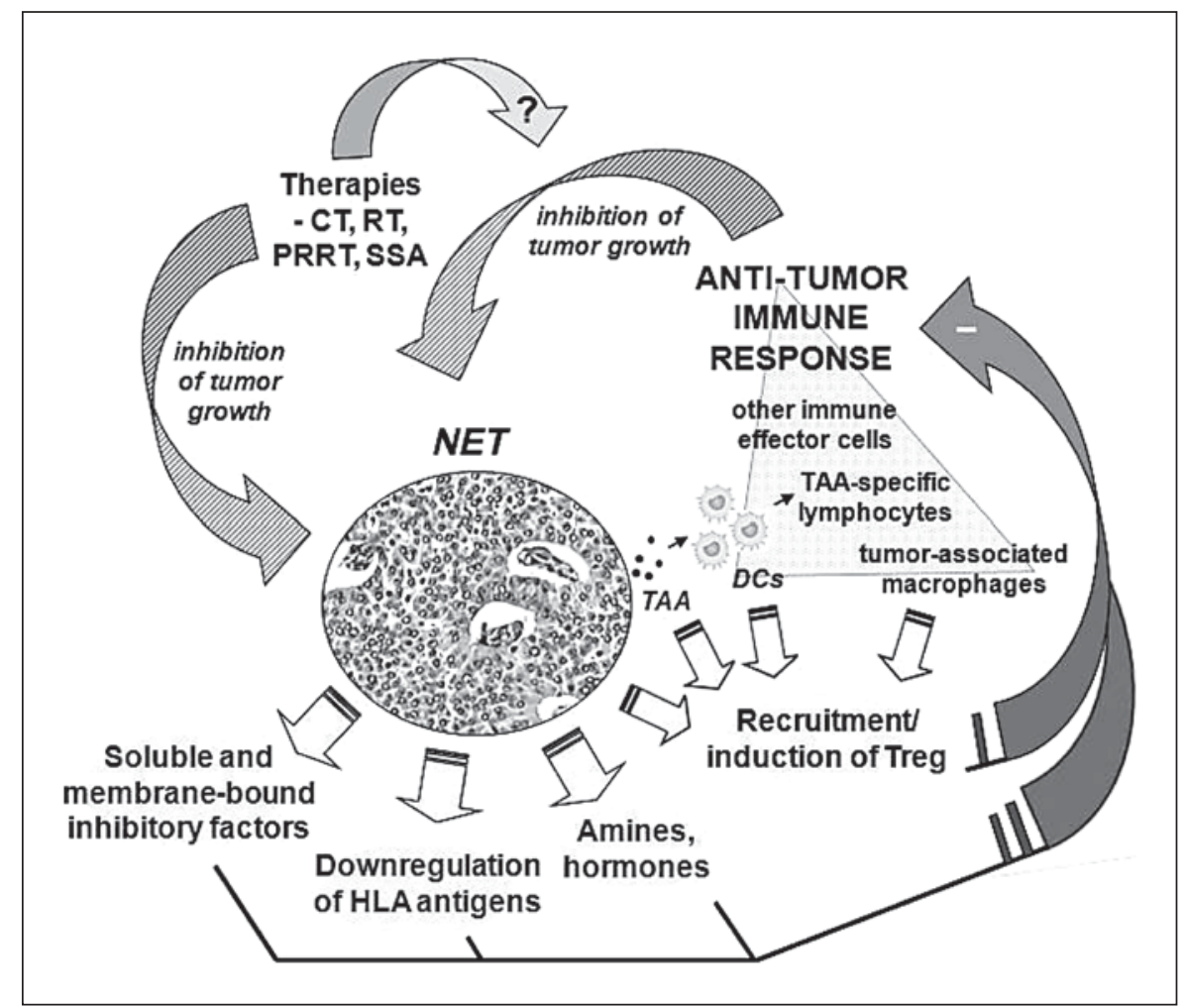

IL-1 $\beta$ were significantly lower, and concentrations of the Treg cytokine TGF- $\beta$ were increased, even though not significantly. After polyclonal activation, patients' T cells proliferated less than those from controls, possibly because of an anergized state caused by carcinoid-associated Treg [62]. NET-infiltrating Treg have been detected by immunohistochemistry for single Treg markers [62, 63], even though such an approach is not optimal to identify Treg and no Treg within NETs have been reported too [61]. Treg infiltration tended to be heavier in metastases than in primary carcinoid tumors [62]. In NET liver metastases (most from pancreatic NETs) it was significantly denser in intermediate/high-grade than low-grade lesions and correlated with a shorter overall survival in univariate analysis [63].

In Merkel cell carcinoma, a higher number of intratumoral mast cells was a predictor of shorter survival. A possible explanation is that mast cells may also stimulate immunosuppression, along with angiogenesis, tumor proliferation, and extracellular matrix degradation [70].

Even before most of the aforementioned data were available, pioneering reports about $\mathrm{DC}$ vaccination NETs were published [71, 72]. Briefly, for DC vaccination DCs are generated and/or purified ex vivo, loaded with TAA, and administered back to a patient. DCs pulsed with TAA should cause the activation of tumor-specific $T$ cells, and eventually induce an anti-tumor response reducing or arresting tumor outgrowth; this really happens, but to a variable extent, largely depending on technical issues as the choice of the TAA, the way they are delivered into DCs, the route and schedule of TAA-loaded DC administration (for a review, see [44]). Even though few patients, especially affected by medullary thyroid carcinoma [72, 73], have received DC immunotherapy for NETs so far, the field is rapidly expanding and great hopes are pinned on it $[74,75]$.

\section{Conclusions}

Although a clear, comprehensive picture of how the DES and the immune system influence each other has not yet been established, our knowledge has remarkably grown. Research on animal models has shed light on the physiological, significant modulation of immune functions by neuropeptides, and has opened exciting therapy perspectives. These mainly concern neuropeptides such as VIP or CST, which can inhibit exuberant and thus det- 
rimental responses of both innate and adaptive immunity. Nevertheless, the puzzle is far from being solved. For instance, VIP-deficient mice have recently been found to be resistant to experimental autoimmune encephalitis, a model of multiple sclerosis, because VIP exerts an unanticipated, permissive role in the $\mathrm{CD} 4+\mathrm{T}$ cell infiltration of the CNS [76].

In contrast to the wealth of information from basic and translational studies, there is very little evidence that the preclinical findings about DES-immune interactions apply to humans. Neither can data from animals be translated into the human situation without verification, because of differences between species in the expression pattern of neuropeptides and their receptors. As for SSTRs and SRIH/CST, SSTR4 is abundantly expressed in rodent immune cells [21], its expression in human immune cells, if any, has however been reported to be negligible [10, 11], but for one immunohistochemistry study [21].
The awareness that the immune system reacts to the development of any tumor has prompted the study of the immune response to NETs. Although promising, the preliminary, small-sized clinical trials of DC vaccination have left open many issues about the optimal immunization strategy, which should be defined before proceeding to a direct comparison with the current best treatment options for NETs. Further research on the immune reaction to NETs may also lead to the identification of new prognostic markers (e.g. the degree of lymphocyte infiltration) and the establishment of other types of immunotherapy, such as adoptive tumor-specific T cell transfer or targeting of tumor-associated Treg.

\section{Disclosure Statement}

P.A. and D.F. report no conflict of interest in the present paper.

\section{References}

1 Montuenga LM, Guembe L, Burrell MA, Bodegas ME, Calvo A, Sola JJ, Sesma P, Villaro AC: The diffuse endocrine system: from embryogenesis to carcinogenesis. Prog Histochem Cytochem 2003;38:155-272.

2 Rindi G, Leiter AB, Kopin AS, Bordi C, Solcia $\mathrm{E}$ : The 'normal' endocrine cell of the gut: changing concepts and new evidences. Ann NY Acad Sci 2004;1014:1-12.

$\checkmark 3$ Chaplin DD: Overview of the immune response. J Allergy Clin Immunol 2010; 125(suppl 2):S3-S23.

-4 Ferone D, van Hagen PM, Pivonello R, Colao A, Lamberts SW, Hofland LJ: Physiological and pathophysiological role of somatostatin receptors in the human thymus. Eur J Endocrinol 2000;143(suppl 1):S27-S34.

5 ten Bokum AM, Hofland LJ, de Jong G, Bouma J, Melief MJ, Kwekkeboom DJ, Schonbrunn A, Mooy CM, Laman JD, Lamberts SW, van Hagen PM: Immunohistochemical localization of somatostatin receptor sst $2 \mathrm{~A}$ in sarcoid granulomas. Eur J Clin Invest 1999;29:630-636.

6 Ferone D, Pivonello R, Van Hagen PM, Dalm VA, Lichtenauer-Kaligis EG, Waaijers M, Van Koetsveld PM, Mooy DM, Colao A, Minuto F, Lamberts SW, Hofland LJ: Quantitative and functional expression of somatostatin receptor subtypes in human thymocytes. Am J Physiol Endocrinol Metab 2002;283:E1056-E1066.

7 Dalm VA, van Hagen PM, van Koetsveld PM, Achilefu S, Houtsmuller AB, Pols DH, van der Lely AJ, Lamberts SW, Hofland LJ: Expression of somatostatin, cortistatin, and so- matostatin receptors in human monocytes, macrophages, and dendritic cells. Am J Physiol Endocrinol Metab 2003;285:E344E353.

8 Lichtenauer-Kaligis EG, Dalm VA, Oomen SP, Mooij DM, van Hagen PM, Lamberts SW, Hofland LJ: Differential expression of somatostatin receptor subtypes in human peripheral blood mononuclear cell subsets. Eur J Endocrinol 2004;150:565-577.

-9 Armani C, Catalani E, Balbarini A, Bagnoli P, Cervia D: Expression, pharmacology, and functional role of somatostatin receptor subtypes 1 and 2 in human macrophages. J Leukoc Biol 2007;81:845-855.

10 Taniyama Y, Suzuki T, Mikami Y, Moriya T, Satomi S, Sasano H: Systemic distribution of somatostatin receptor subtypes in human: an immunohistochemical study. Endocr J 2005;52:605-611.

11 Hagströmer L, Emtestam L, Stridsberg M, Talme T: Expression pattern of somatostatin receptor subtypes 1-5 in human skin: an immunohistochemical study of healthy subjects and patients with psoriasis or atopic dermatitis. Exp Dermatol 2006;15:950-957.

12 Ferone D, Pivonello R, Kwekkeboom DJ, Gatto F, Ameri P, Colao A, de Krijger RR, Minuto F, Lamberts SW, van Hagen PM, Hofland LJ: Immunohistochemical localization and quantitative expression of somatostatin receptors in normal human spleen and thymus: implications for the in vivo visualization during somatostatin receptor scintigraphy. J Endocrinol Invest 2011, Epub ahead of print.
13 Ameri P, Gatto F, Arvigo M, Villa G, Resmini E, Minuto F, Murialdo G, Ferone D: Somatostatin receptor scintigraphy in thoracic diseases. J Endocrinol Invest 2007;30:889902.

14 Pintér E, Helyes Z, Szolcsányi J: Inhibitory effect of somatostatin on inflammation and nociception. Pharmacol Ther 2006;112:440456.

15 Bánvölgyi A, Pozsgai G, Brain SD, Helyes ZS, Szolcsányi J, Ghosh M, Melegh B, Pintér E: Mustard oil induces a transient receptor potential vanilloid 1 receptor-independent neurogenic inflammation and a non-neurogenic cellular inflammatory component in mice. Neuroscience 2004;125:449-459.

16 Ustinova EE, Gutkin DW, Pezzone MA: Sensitization of pelvic nerve afferents and mast cell infiltration in the urinary bladder following chronic colonic irritation is mediated by neuropeptides. Am J Physiol Renal Physiol 2007;292:F123-F130.

17 Helyes Z, Elekes K, Sándor K, Szitter I, Kereskai L, Pintér E, Kemény A, Szolcsányi J, McLaughlin L, Vasiliou S, Kipar A, Zimmer A, Hunt SP, Stewart JP, Quinn JP: Involvement of preprotachykinin A gene-encoded peptides and the neurokinin 1 receptor in endotoxin-induced murine airway inflammation. Neuropeptides 2010;44:399-406.

18 Razavi R, Chan Y, Afifiyan FN, Liu XJ, Wan X, Yantha J, Tsui H, Tang L, Tsai S, Santamaria P, Driver JP, Serreze D, Salter MW, Dosch HM: TRPV1+ sensory neurons control beta cell stress and islet inflammation in autoimmune diabetes. Cell 2006;127:1123-1135. 
$>19$ Helyes Z, Elekes K, Németh J, Pozsgai G, Sándor K, Kereskai L, Börzsei R, Pintér E, Szabó A, Szolcsányi J: Role of transient receptor potential vanilloid 1 receptors in endotoxin-induced airway inflammation in the mouse. Am J Physiol Lung Cell Mol Physiol 2007;292:L1173-L1181.

20 Helyes Z, Pintér E, Németh J, Sándor K, Elekes K, Szabó A, Pozsgai G, Keszthelyi D, Kereskai L, Engström M, Wurster S, Szolcsányi J: Effects of the somatostatin receptor subtype 4 selective agonist J-2156 on sensory neuropeptide release and inflammatory reactions in rodents. Br J Pharmacol 2006;149: 405-415.

-21 Varecza Z, Elekes K, László T, Perkecz A, Pintér E, Sándor Z, Szolcsányi J, Keszthelyi D, Szabó A, Sándor K, Molnár TF, Szántó Z, Pongrácz JE, Helyes Z: Expression of the somatostatin receptor subtype 4 in intact and inflamed pulmonary tissues. J Histochem Cytochem 2009;57:1127-1137.

-22 Chowers Y, Cahalon L, Lahav M, Schor H, Tal R, Bar-Meir S, Levite M: Somatostatin through its specific receptor inhibits spontaneous and TNF-alpha- and bacteria-induced IL-8 and IL-1 beta secretion from intestinal epithelial cells. J Immunol 2000;165:2955-2961.

- 23 Karalis K, Mastorakos G, Sano H, Wilder RL, Chrousos GP: Somatostatin may participate in the antiinflammatory actions of glucocorticoids. Endocrinology 1995;136: 4133-4138.

24 Helyes Z, Pintér E, Sándor K, Elekes K, Bánvölgyi A, Keszthelyi D, Szoke E, Tóth DM, Sándor Z, Kereskai L, Pozsgai G, Allen JP, Emson PC, Markovics A, Szolcsányi J: Impaired defense mechanism against inflammation, hyperalgesia, and airway hyperreactivity in somatostatin 4 receptor gene-deleted mice. Proc Natl Acad Sci USA 2009;106: 13088-13093.

25 Van Op den Bosch J, Torfs P, De Winter BY, De Man JG, Pelckmans PA, Van Marck E, Grundy D, Van Nassauw L, Timmermans JP: Effect of genetic SSTR4 ablation on inflammatory peptide and receptor expression in the non-inflamed and inflamed murine intestine. J Cell Mol Med 2009;13:3283-3295.

-26 Siehler S, Nunn C, Hannon J, Feuerbach D, Hoyer D: Pharmacological profile of somatostatin and cortistatin receptors. Mol Cell Endocrinol 2008;286:26-34.

-27 Robas N, Mead E, Fidock M: MrgX2 is a high potency cortistatin receptor expressed in dorsal root ganglion. J Biol Chem 2003;278: 44400-44404.

28 Gonzalez-Rey E, Chorny A, Robledo G, Delgado $M$ : Cortistatin, a new antiinflammatory peptide with therapeutic effect on lethal endotoxemia. J Exp Med 2006;203:563-571.

-29 Gonzalez-Rey E, Varela N, Sheibanie AF, Chorny A, Ganea D, Delgado M: Cortistatin, an antiinflammatory peptide with therapeutic action in inflammatory bowel disease. Proc Natl Acad Sci USA 2006;103:42284233.
30 Gonzalez-Rey E, Chorny A, Del Moral RG, Varela N, Delgado M: Therapeutic effect of cortistatin on experimental arthritis by downregulating inflammatory and Th1 responses. Ann Rheum Dis 2007;66:582-588.

31 Dello Russo C, Lisi L, Navarra P, Tringali G: Diverging effects of cortistatin and somatostatin on the production and release of prostanoids from rat cortical microglia and astrocytes. J Neuroimmunol 2009;213:78-83.

32 Gonzalez-Rey E, Chorny A, Delgado M: Regulation of immune tolerance by anti-inflammatory neuropeptides. Nat Rev Immunol 2007;7:52-63.

33 Gonzalez-Rey E, Delgado M: Vasoactive intestinal peptide inhibits cyclooxygenase-2 expression in activated macrophages, $\mathrm{mi}-$ croglia, and dendritic cells. Brain Behav Immun 2008;22:35-41.

34 Chorny A, Delgado M: Neuropeptides rescue mice from lethal sepsis by down-regulating secretion of the late-acting inflammatory mediator high mobility group box 1 . Am J Pathol 2008;172:1297-1307.

35 Chorny A, Anderson P, Gonzalez-Rey E, Delgado M: Ghrelin protects against experimental sepsis by inhibiting high-mobility group box 1 release and by killing bacteria. J Immunol 2008; 180:8369-8377.

36 Gonzalez-Rey E, Ganea D, Delgado M: Neuropeptides: keeping the balance between pathogen immunity and immune tolerance. Curr Opin Pharmacol 2010;10:473-481.

37 Suto B, Bagoly T, Borzsei R, Lengl O, Szolcsanyi J, Nemeth T, Loibl C, Bardonicsek Z, Pinter E, Helyes Z: Surgery and sepsis increase somatostatin-like immunoreactivity in the human plasma. Peptides 2010;31: 1208-1212.

38 Sciola V, Massironi S, Conte D, Caprioli F, Ferrero S, Ciafardini C, Peracchi M, Bardella MT, Piodi L: Plasma chromogranin A in patients with inflammatory bowel disease. Inflamm Bowel Dis 2009;15:867-871.

39 Capellino S, Lowin T, Angele P, Falk W, Grifka J, Straub RH: Increased chromogranin A levels indicate sympathetic hyperactivity in patients with rheumatoid arthritis and systemic lupus erythematosus. J Rheumatol 2008;35:91-99.

40 Sørhaug S, Langhammer A, Waldum HL Hveem K, Steinshamn S: Increased serum levels of chromogranin A in male smokers with airway obstruction. Eur Respir J 2006; 28542-28548.

41 Di Comite G, Marinosci A, Di Matteo P, Manfredi A, Rovere-Querini P, Baldissera E, Aiello P, Corti A, Sabbadini MG: Neuroendocrine modulation induced by selective blockade of TNF-alpha in rheumatoid arthritis. Ann NY Acad Sci 2006;1069:428437.

42 Di Comite G, Rossi CM, Marinosci A, Lolmede K, Baldissera E, Aiello P, Mueller RB, Herrmann M, Voll RE, Rovere-Querini P, Sabbadini MG, Corti A, Manfredi AA: Circulating chromogranin A reveals extra-ar- ticular involvement in patients with rheumatoid arthritis and curbs TNF-alpha-elicited endothelial activation. J Leukoc Biol 2009; 85:81-87.

43 Levite M: Neuropeptides, by direct interaction with $\mathrm{T}$ cells, induce cytokine secretion and break the commitment to a distinct $\mathrm{T}$ helper phenotype. Proc Natl Acad Sci USA 1998;95:12544-12549.

44 Weinstock JV, Elliott D: The somatostatin immunoregulatory circuit present at sites of chronic inflammation. Eur J Endocrinol 2000;143(suppl 1):S15-S19.

-45 Herberth G, Daegelmann C, Weber A, Röder $S$, Giese T, Krämer U, Schins RP, Behrendt $H$, Borte M, Lehmann I; LISAplus Study Group: Association of neuropeptides with Th1/Th2 balance and allergic sensitization in children. Clin Exp Allergy 2006;36:1408-1416.

$\checkmark 46$ Brod SA, Hood ZM: Ingested (oral) SST inhibits EAE. Autoimmunity 2011;44:437-443.

47 Wing K, Sakaguchi S: Regulatory T cells exert checks and balances on self tolerance and autoimmunity. Nat Immunol 2010;11:7-13.

48 Fontenot JD, Gavin MA, Rudensky AY: Foxp3 programs the development and function of CD $4+\mathrm{CD} 25+$ regulatory $\mathrm{T}$ cells. Nat Immunol 2003;4:330-336.

-49 Yamagiwa S, GrayJD, Hashimoto S, Horwitz DA: A role for TGF-beta in the generation and expansion of $\mathrm{CD} 4+\mathrm{CD} 25+$ regulatory $\mathrm{T}$ cells from human peripheral blood. J Immunol 2001;166:7282-7289.

50 Anderson P, Gonzalez-Rey E: Vasoactive intestinal peptide induces cell cycle arrest and regulatory functions in human $\mathrm{T}$ cells at multiple levels. Mol Cell Biol 2010;30:25372551.

-51 Prasse A, Zissel G, Lützen N, Schupp J, Schmiedlin R, Gonzalez-Rey E, Rensing-Ehl A, Bacher G, Cavalli V, Bevec D, Delgado M, Müller-Quernheim J: Inhaled vasoactive intestinal peptide exerts immunoregulatory effects in sarcoidosis. Am J Respir Crit Care Med 2010;182:540-548.

-52 Pozo D, Anderson P, Gonzalez-Rey E: Induction of alloantigen-specific human $\mathrm{T}$ regulatory cells by vasoactive intestinal peptide. J Immunol 2009;183:4346-4359.

53 Wang J, Zhao R, Zhang F, Li J, Huo B, Cao Y, Dou K: Control of allograft rejection in mice by applying a novel neuropeptide, cortistatin. Adv Ther 2008;25:1331-1341.

54 Mignini F, Sabbatini M, D’Andrea V, Cavallotti C: Neuropeptides of human thymus in normal and pathological conditions. Peptides DOI:10.1016/j.peptides.2011.01.022.

55 Amantini C, Mosca M, Lucciarini R, Perfumi MC, Santoni G: Thiorphan-induced survival and proliferation of rat thymocytes by activation of Akt/survivin pathway and inhibition of caspase-3 activity. J Pharmacol Exp Ther 2008;327:215-225.

56 Schott M: Immunesurveillance by dendritic cells: potential implication for immunotherapy of endocrine cancers. Endocr Relat Cancer 2006;13:779-795. 
57 Wuttke M, Papewalis C, Jacobs B, Schott M: Identifying tumor antigens in endocrine malignancies. Trends Endocrinol Metab 2009;20:122-129.

- 58 Oberg K, Ferone D, Kaltsas G, Knigge UP, Taal B, Plöckinger U; Mallorca Consensus Conference participants; European Neuroendocrine Tumor Society: ENETS Consensus Guidelines for the Standards of Care in Neuroendocrine Tumors: biotherapy. Neuroendocrinology 2009;90:209-213.

59 Vitale G, van Koetsveld PM, de Herder WW, van der Wansem K, Janssen JA, Colao A, Lombardi G, Lamberts SW, Hofland LJ: Effects of type I interferons on IGF-mediated autocrine/paracrine growth of human neuroendocrine tumor cells. Am J Physiol Endocrinol Metab 2009;296:E559-E566.

-60 Erdos M, Garami M, Rákóczi E, Zalatnai A, Steinbach D, Baumann U, Kropshofer G, Tóth B, Maródi L: Neuroendocrine carcinoma associated with X-linked hyper-immunoglobulin M syndrome: report of four cases and review of the literature. Clin Immunol 2008; 129:455-461.

-61 Ryschich E, Autschbach F, Eisold S, Klar E, Buchler MW, Schmidt J: Expression of HLA class I/II antigens and $\mathrm{T}$ cell immune response in human neuroendocrine tumors of the pancreas. Tissue Antigens 2003;62:4854.

62 Vikman S, Sommaggio R, De La Torre M, Oberg K, Essand M, Giandomenico V, Los$\operatorname{kog} \mathrm{A}$, Totterman TH: Midgut carcinoid patients display increased numbers of regulatory $\mathrm{T}$ cells in peripheral blood with infiltration into tumor tissue. Acta Oncol 2009;48: 391-400.
63 Katz SC, Donkor C, Glasgow K, Pillarisetty VG, Gönen M, Espat NJ, Klimstra DS, D’Angelica MI, Allen PJ, Jarnagin W, Dematteo RP, Brennan MF, Tang LH: T cell infiltrate and outcome following resection of intermediate-grade primary neuroendocrine tumours and liver metastases. HPB (Oxford) 2010;12:674-683.

64 Vikman S, Essand M, Cunningham JL, de la Torre M, Oberg K, Tötterman TH, Giandomenico V: Gene expression in midgut carcinoid tumors: potential targets for immunotherapy. Acta Oncol 2005;44:32-40.

65 Vikman S, Giandomenico V, Sommaggio R, Oberg K, Essand M, Tötterman TH: CD8+ T cells against multiple tumor-associated antigens in peripheral blood of midgut carcinoid patients. Cancer Immunol Immunother 2008;57:399-409.

66 Papewalis C, Jacobs B, Wuttke M, Ullrich E, Baehring T, Fenk R, Willenberg HS, Schinner S, Cohnen M, Seissler J, Zacharowski K, Scherbaum WA, Schott M: IFN-alpha skews monocytes into CD56+-expressing dendritic cells with potent functional activities in vitro and in vivo. J Immunol 2008; 180:14621470.

67 Papewalis C, Jacobs B, Baran AM, Ehlers M, Stoecklein NH, Willenberg HS, Schinner S, Anlauf M, Raffel A, Cupisti K, Fenk R, Scherbaum WA, Schott M: Increased numbers of tumor-lysing monocytes in cancer patients. Mol Cell Endocrinol 2011;337:5261.

68 Katsenelson NS, Shurin GV, Bykovskaia SN, Shogan J, Shurin MR: Human small cell lung carcinoma and carcinoid tumor regulate dendritic cell maturation and function. Mod Pathol 2001;14:40-45.

69 Nishikawa H, Sakaguchi S: Regulatory T cells in tumor immunity. Int J Cancer 2010; 127:759-767.

70 Beer TW, Ng LB, Murray K: Mast cells have prognostic value in Merkel cell carcinoma. Am J Dermatopathol 2008;30:27-30.
Schott M, Seissler J, Feldkamp J, von Schilling C, Scherbaum WA: Dendritic cell immunotherapy induces antitumour response in parathyroid carcinoma and neuroendocrine pancreas carcinoma. Horm Metab Res 1999;31:662-664.

-72 Schott M, Seissler J, Lettmann M, Fouxon V, Scherbaum WA, Feldkamp J: Immunotherapy for medullary thyroid carcinoma by dendritic cell vaccination. J Clin Endocrinol Metab 2001;86:4965-4969.

73 Bachleitner-Hofmann T, Friedl J, Hassler M, Hayden H, Dubsky P, Sachet M, Rieder E, Pfragner R, Brostjan C, Riss S, Niederle B, Gnant M, Stift A: Pilot trial of autologous dendritic cells loaded with tumor lysate(s) from allogeneic tumor cell lines in patients with metastatic medullary thyroid carcinoma. Oncol Rep 2009;21:1585-1592.

74 Papewalis C, Wuttke M, Seissler J, Meyer Y, Kessler C, Jacobs B, Ullrich E, Willenberg HS, Schinner S, Baehring T, Scherbaum WA, Schott M: Dendritic cell vaccination with xenogenic polypeptide hormone induces tumor rejection in neuroendocrine cancer. Clin Cancer Res 2008;14:4298-4305.

75 Papewalis C, Kouatchoua C, Ehlers M, Jacobs B, Porwol D, Schinner S, Willenberg HS, Anlauf M, Raffel A, Eisenhofer G, Neumann HP, Bornstein SR, Scherbaum WA, Schott M: Chromogranin A as potential target for immunotherapy of malignant pheochromocytoma. Mol Cell Endocrinol 2011; 335:69-77.

76 Abad C, Tan YV, Lopez R, Nobuta H, Dong $\mathrm{H}$, Phan P, Feng JM, Campagnoni AT, Waschek JA: Vasoactive intestinal peptide loss leads to impaired CNS parenchymal T-cell infiltration and resistance to experimental autoimmune encephalomyelitis. Proc Natl Acad Sci USA 2010;107:19555-19560. 